\title{
ПРАВО ЛЮДИНИ НА ПРИВАТНІСТЬ ПЕРСОНІФІКОВАНОЇ ІНФОРМАЦІЇ В УМОВАХ ГЛОБАЛІЗАЦІЙНИХ ПРОЦЕСІВ
}

Саснко М. I.

\section{ВСТУП}

У сучасний періоду у зв'язку з інтенсивним розвитком засобів збору, обробки, зберігання, передачі різних видів інформації, із глобальним наступом так званого віртуального простору, розвитком потужних мереж комунікаційних систем, які здійснюють трансграничні передачі відомостей, коли збільшуються можливості несанкціонованого доступу до інформації про особу, інших видів інформації, використання якої може спричинити шкоду, зокрема, законним інтересам конкретної людини, все більш актуальною стає проблема необхідності захисту конфіденційної інформації про фізичну особу персональних даних.

Як наголошують вітчизняні спеціалісти, впровадження автоматизованих інформаційних систем, телекомунікаційних мереж, баз, банків даних спричинює не тільки позитивні, але й негативні наслідки, а саме нові форми несанкціонованого доступу до інформації або ж комп'ютерні злочини, об'єктом яких є суспільні відносини із забезпечення безпеки комп'ютерної інформації, інформаційних систем та комп'ютерних мереж ${ }^{1}$.

Збільшення обсягів і напрямів використання персоніфікованої інформації в різних сферах суспільного життя, її передача через кордони новітніми комунікаційними засобами викликає необхідність належного правового регулювання відносин, пов'язаних із використанням персональної інформації як для забезпечення прав і свобод людини, так і для ефективної реалізації правомірних інтересів інших осіб і держави. Нині гостро відчувається потреба в широкому науковому узагальненні чинних норм міжнародного і національного права, здобутків правової думки в цій галузі з метою визначення основних елементів і особливостей правового захисту права людини на приватність персоніфікованої інформації.

Комплексне дослідження проблеми регулювання відносин, що виникають у зв’язку з обробкою (збиранням, зберіганням,

1 Азаров Д.С. Кримінальна відповідальність за злочини у сфері комп’ютерної інформації : автореф. дис. на здобуття ступеня канд. юрид. наук : 12.00.08. 2003, с. 14-15. 
використанням, поширенням) інформації про особу, є необхідним також для забезпечення ефективної реалізації гарантованого ст. 31 Конституції України права громадян на таємницю листування, телефонних розмов, телеграфної та іншої кореспонденції, а також проголошеного в ст. 32 Конституції України права на невтручання у приватне і сімейне життя ${ }^{2}$.

Крім того, невідповідність національних правових положень у цій галузі міжнародно-правовим стандартам загрожує застосуванням обмежень на передачу персоніфікованої інформації громадян інших країн до України, а це матиме негативні політичні й економічні наслідки для держави і вітчизняних суб'єктів господарювання, створюватиме перешкоди для міжнародного співробітництва в багатьох сферах (зокрема, в питаннях боротьби з тероризмом та злочинністю), де відбувається міжнародний обмін інформацією про особу.

У вітчизняній юриспруденції активно розвивається теорія міжнародно-правового захисту прав людини, досліджуються питання реформування правової системи України відповідно до міжнародно-правових стандартів, зокрема в працях О. Жуковської ${ }^{3}$, С. Захарова ${ }^{4}$, I. Рапп, В. Іванова ${ }^{5}$ М. Важорової 6 . Однак специфічним питанням правового захисту права людини на приватність персоніфікованої інформації приділяється незначна увага.

Розглядаються окремі ії аспекти впрацях О. Баранова ${ }^{7}$, Т. Костецької ${ }^{8}$, В. Брижка ${ }^{9}$, Д. Павленка ${ }^{10}$ та ін. Нині є нагальна потреба в широкому

\footnotetext{
2 Конституція України :Закон Українистаномна20.02.2020.URL:http://zakon4.rada.gov.ua/ laws/show/254к/96-вр.

3 Жуковська О. Право на свободу слова та інформації в українському законодавстві та судовій практиці (деякі аспекти проблеми). Свобода висловлювань і приватність. 2002. № 2. C. 4-12.
}

4 Захаров Є. Аналіз доступу до інформації про незаконні дії співробітників правоохоронних органів. Свобода висловлювань і приватність. 2002. № 2. С. 12-16.

5 Іванов В.Ф. Інформаційне законодавство: український та зарубіжний досвід. Київ : Центр вільн. преси, 1999. 210 с.

6 Важорова М.А. История возникновения и становления института персональных данных. URL: http://www.moluch.ru/conf/law/archive/37/365.

7 Права человека и защита персональных данных / за ред. А.А. Баранова и др. Киев : Гос. комитет связи и информации Украины, 2000. 280 с

8 Костецька Т.А. Право на інформацію в Україні. НАН України; Ін-т держави і права ім. В.М. Корецького. Київ : Вища шк. права. 1998. С. 5, 25, 28, 31.

9 Брижко В.М. Організаційно-правовий захист персональних даних. Бюлетень з обміну досвідом роботи : наук.-практ. вид. МВС України. 2003. № 144. С. 27-33.

10 Павленко Д. Як захистити персональні дані. URL: http://www.epravda.com.ua/ columns/2011/09/30/300156. 
науковому узагальненні чинних норм європейського i національного права, здобутків правової думки в цій галузі з метою визначення основних складників і особливостей міжнародно-правового захисту права людини на приватність персоніфікованої інформації в умовах глобалізації. Відсутність грунтовних досліджень зазначених питань у національній науці міжнародного права ускладнює процес пошуку адекватної моделі національного механізму регулювання відносин із використання персоніфікованої інформації, узгодженої з міжнародноправовими стандартами, яка гарантувала б ефективний захист прав і свобод громадян України. Дослідження зумовлюється актуальністю щодо виникнення та значного поширення ризиків життю, здоров’ю, репутації, добробуту людини внаслідок неправомірного збирання й використання персоніфікованої інформації, тобто від небажаного вторгнення у внутрішню сферу життя людини, яка охороняється правом на повагу до приватного життя.

У дослідженні зроблена спроба вирішення нагальних проблем теоретико-правової науки та практики щодо приватності персоніфікованої інформації про особу за рахунок розширення наукової та нормативно-правової бази дослідження, шляхом долучення до наукового обігу сучасних напрацювань європейського законодавства. Це виводить наукову дискусію щодо права людини на приватність персоніфікованої інформації на якісно новий рівень, актуалізує пошук відповідей на новітні виклики приватності, спричинені глобалізаційними процесами в суспільстві, і дає перспективи подальшого розвитку законодавства з питань приватності персоніфікованої інформації з урахуванням сучасних тенденцій у світі.

\section{1. Теоретико-правові засади регулювання персоніфікованої інформації в аспекті світових тенденцій розвитку IT}

3 точки зору соціально-філософської концепції поняття «інформація» нерозривно пов’язане 3 категорією «відображення». За визначенням, яке пропонує вітчизняний дослідник, професор Н. Джинчарадзе: «Інформація - це найвищий, найскладніший результат упорядкованого відображення у вигляді повідомлень, знань, відомостей про природу, суспільство, загалом про об’єктивну реальність, які охоплюють усі сфери людської діяльності, використовуються в процесі спілкування, управління, виробництва, пізнання, творчості, виховання, освіти тощо» ${ }^{11}$. Інформація розглядається як діалектична єдність поновлення

\footnotetext{
11 Джинчарадзе Н.Г. Інформаційна культура. Київ : Укр. пропілеї, 1999. 148 с.
} 
різноманітності і як її обмеження. Основна функція інформації-давати уявлення (інформувати) про об'єкт, відображаючи його властивості.

Персональна інформація є різновидом інформації, яка відображає як індивідуальність окремої особи, так і її загальнолюдські біологічні й соціальні властивості. Персональна інформація відображає людську різноманітність, індивідуальність кожної людини як носія унікальних елементів фізичної, фізіологічної, психічної, економічної, культурної або соціальної тотожності. Отже, визначальною ознакою персональної інформації є іiї індивідуалізований характер, здатність ідентифікувати конкретну особу за допомогою тих чи інших критеріїв.

Під час такої ідентифікації відбувається процес персоніфікації тих чи інших відомостей, тобто прив'язування їх до конкретної людини. Інформація, яка ідентифікує (ототожнює), дає змогу безпосередньо або за допомогою інших чинників ідентифікувати особу, є персональною інформацією. Разом із тим відомості (як документовані, так і в усному вигляді) є формою відображення біологічної й соціальної тотожності, а також індивідуальності кожної людини.

Саме для позначення відомостей про особу, які вже зазнали певної обробки людиною, зафіксовані на певному носії, упорядковані і придатні для автоматизованої обробки, варто вживати термін «персональні дані» (лат. personalitas - особистість).

Персоніфікована інформація (від лат. persona - особа і ficatio, від facio - роблю) - інформація, з якої однозначно можна встановити, що вона стосується конкретної особи або ж включає іiї до кола осіб, яких ця інформація стосується (див. також інформація про особу) $)^{12}$.

Неправомірне збирання, використання й поширення персональної інформації завдає шкоди уявленню про індивіда. Це не тільки біографічні дані, як-от: прізвище, ім'я, по батькові, дата і місце народження особи, національність, релігійні, політичні чи філософські переконання, освіта, місця навчання і роботи, відомості про сімейний стан, наявність дітей, ставлення до військової служби. До персональної інформації також належать відомості про матеріально-фінансовий стан (банківські рахунки, платежі по них, нерухоме та рухоме майно, майнові права), стан здоров'я, особисті стосунки приватного характеру та багато інших відомостей у матеріальній формі в різних сферах суспільного життя, які створюються, збираються,

12 Стефанчук Р.О. До питання забезпечення цивільно-правової охорони приватного життя фізичної особи: досвід України та Німеччини. Університетські наукові записки. 2005. № 4. C. 68 . 
зберігаються, поширюються та використовуються в інший спосіб як з відома особи - суб’єкта даних, так і без іії відома. Ця інформація дає можливість суспільству оцінювати людину як індивідуальність, формувати iї репутацію (лат. reputatio - оцінка).

Якщо ще півстоліття тому для здобуття інформації про людину необхідно було витратити значні зусилля, сучасний рівень розвитку технологій дає змогу здійснити обробку даних про тисячі людей за лічені секунди і без надмірних витрат. А поєднання неточних чи застарілих персональних даних створювати неспотворене уявлення про особу. Практика створення цифрового образу особи набула поширення за допомогою так званих процедур «зіставлення даних» (data matching - англ.), під час якої здійснюється збирання, зіставлення й об'єднання персоніфікованих даних, які містяться в різних базах даних; а також «профілювання» (profiling - англ.) - створення профілю людини, сукупності характеристик особи за певними критеріями на підставі аналізу відомостей про особу з різних баз даних. Ці види таємного збирання відомостей про особу отримали складно скорочену назву «дейтавейленс» (англ. dataveillance), що перекладається як «стеження за даними».

Можливості технічних засобів, що дають змогу збирати й обробляти персоніфіковану інформацію, постійно й стрімко розширюються; технології вдосконалюються, а ціна на них знижується. Навіть за звичайними технологіями збирання інформації значна кількість персональної інформації постійно збирається. Будь-яка платіжна операція, будь-то покупка, продаж чи інвестування, створює сукупність персональних даних. Ця інформація використовується як із комерційною метою, так і для звітування перед фіскальними органами держави. Певні соціальні ризики виникають у зв'язку з використанням багатофункціональних кредитних карток із мікропроцесором (англ. multifunctionsmart card), так званих «смарт-карток», які використовуються для ідентифікації особи в різних сферах суспільних відносин. Серед найбільш важливих - ризики, які пов'язані з ідентифікацією особи й можливістю неправомірного використання персоніфікованої інформації. Питання захисту від «крадіжок ідентичності» $€$, серед іншого, одним із завдань Міжнародної організації поліції - Інтерполу.

Загроза неадекватного сприйняття оточуючими, дискримінації за якоюсь ознакою, іншого протиправного використання персоніфікованої інформації вимагає передбачення іiі потенційної «уразливості» для людини. Урахування особистих інтересів особи, які неможливо повною мірою охопити в узагальнених нормативних приписах, 
потребує законодавчого віднесення об'ємного переліку даних до категорії «уразливих даних» (про расове або етнічне походження чи національність, політичні погляди, релігійні або філософські переконання, членство у профспілках чи громадських організаціях, дані, які стосуються стану здоров'я чи надання медико-санітарної допомоги, сімейних і особистих стосунків приватного характеру чи статевого життя, відомості про кримінальні вчинки чи протиправну поведінку), а також надання особі права самостійно визначати межі циркуляції персоніфікованої інформації в суспільстві ${ }^{13}$.

Для ефективного захисту такої інформації необхідно встановити, яка персональна інформація, для яких цілей, в якому обсязі і яким одержувачам може передаватися. Такий підхід зумовлений тим, що тільки особа, якої стосується персональна інформація, може оцінити уразливість, тобто ймовірний ризик неправомірного використання такої інформації. Це становить основу права на приватність персоніфікованої інформації та усвідомлення такого поняття, як «приватна сфера» життя людини.

У західній правовій доктрині для позначення цього правового інституту використовується термін «прайвесі» (англ. privacy). Найбільш вдалим його перекладом українською мовою $є$ «приватність», яке походить від слова «приватний». Воно характеризує якісний стан об'єкта, що випливає з його належності до «приватної сфери» життя людини. До того ж цей термін одразу асоціюється з тим, що належить безпосередньо приватній особі і є недоступним для людського загалу, є «приватною справою» і протиставляється публічному. Його антонім - «публічність», що означає відкритість для публіки, гласність.

Перша концепція права на приватність пройшла судову апробацію в США. У практиці американських судів нерідко розглядалися випадки комерційного використання персональних характеристик індивідів, таких як зовнішній вигляд, ім'я та голос. Нерідко такі випадки порушення прав людини супроводжувалися порушеннями права власності. Американські суди вбачали в цих індивідуальних рисах особистості, на які посягали інші особи, певний об'єкт захисту майнового інтересу. Традиційне західне уявлення про право на приватність бере свій витік із права на недоторканність домоволодіння, а західна доктрина приватності має територіальний характер, оскільки захищає персональний життєвий простір особи.

13 Обуховська T.I. Теоретичні засади регулювання інформації про особу в умовах розвитку інформаційних технологій. Вісник НАДУ. 2015. № 2. С. 120-125. 
Американський юрист Вільям Л. Проссер після вивчення прецедентів, створених американськими судами під час розгляду справ щодо втручання у приватне життя людини, запропонував таку класифікацію: розкриття фактів, що стосуються приватного життя; повідомлення неправдивої інформації про людину; неправомірне використання зображень зовнішності, голосу людини i, нарешті, останнє - фізичне домагання ${ }^{14}$.

Свою класифікацію втручань у приватне життя запропонував шведський дослідник С. Стромхольм ${ }^{15}$. Виділивши 14 видів неправомірних посягань на приватність, він об'єднав їх у три групи, виходячи зі спрямованості дій правопорушників: дії, спрямовані на вторгнення у приватну сферу життя особи, незаконний обшук, відправлення листів з образами, домагання телефонними дзвінками; незаконні дії, завдяки яким порушники одержують інформацію про приватне життя особи: підслухування телефонних розмов, перехоплення кореспонденції тощо; поширення чи інше використання відомостей про приватне життя особи: публікація у пресі інформації про приватне життя, використання імені і зовнішнього вигляду особи.

Оскільки саме право людини на приватність персональної інформації стає об'єктом правового захисту, цей вид приватності одержав назву «інформаційна приватність» (англ. informational privacy). Цей вид приватності також має територіальний вимір, оскільки інформаційні потоки циркулюють у певному фізичному просторі. Людина ж є основним джерелом інформації, яка генерується із середині ії життєвого простору, і є споживачем інформації, яка надходить до неї ззовні. Але слід розмежувати сфери, в яких реалізується суспільна активність людини. Це дає змогу розподілити загальну проблему захисту приватності людини на сектори, які вимагають окремого законодавчого регулювання. За цим критерієм можна виділити чотири види приватності: інформаційну приватність, якою охоплюються правила стосовно збирання й обробки персональних даних; тілесну (фізичну) приватність, яка стосується захисту фізичної недоторканності людини від примусових процедур, таких як наркологічне тестування та ін.; комунікаційну приватність, яка охоплює безпеку й конфіденційність поштових відправлень, телефонних розмов, електронної кореспонденції та інших

\footnotetext{
14 Prosser William L. Handbook of the Law of Torts. St. Paul : West Publication Corp., 1964. P. $810-81$.

15 Stromholm S. La protection de la vie privee - essai demorphologie juridique compare. Copyright and jurisprudence. 1983. P. 213-238.
} 
форм зв'язку; територіальну приватність, яка стосується встановлення правових рамок для захисту від втручання в сімейну сферу, інше оточення, на робочому місці або в транспортному засобі. Така класифікація дає можливість зрозуміти комплексність і взаємопов'язаність усіх елементів цього поняття. Разом із тим питання правового регулювання збирання й передачі інформації є ключовими для захисту приватності інформації про особистість. При цьому комунікації й бази даних виступають як носії персональної інформації. Відокремленням цього об'єкта правового регулювання від сфери «інформаційна приватність» в окреме поняття «комунікаційна приватність» відділяється певна частина від цілого. Очевидно, розвиток інформаційних технологій поступово стирає грані між цими поняттями. Стрімке поширення електронних комунікацій, в яких повідомлення передаються у цифровому вигляді, не дає змоги технічно й нормативно розмежувати, де закінчується комунікаційна приватність і починається приватність персональних даних.

Таким чином, особливістю захисту права на приватність персоніфікованої інформації $є$ спрямованість на забезпечення свободи особи у визначенні просторових і часових меж інформаційного контакту з іншими суб'єктами, підконтрольності циркуляції персональної інформації в суспільстві, що є важливим для підтримання автономії особи, захисту приватної сфери ії життя.

Проблема забезпечення права на приватність користувачів Інтернету ускладнюється екстериторіальним характером інформаційного обміну. Інтернет дає змогу встановлювати безпосередній контакт між людиною - суб'єктом даних, який перебуває під юрисдикцією однієї держави, і іншими суб'єктами інформаційного обміну, які можуть перебувати на території інших держав. Забезпечити дію національних положень, а значить, гарантувати належний рівень захисту приватності для своїх громадян у цьому середовищі для держави стає проблематичним. Водночас створення національними урядами штучних перешкод для вільного транскордонного обігу персональної інформації негативно позначатиметься на міжнародному співробітництві в багатьох сферах.

Розуміння цієї проблеми спонукало міжнародне співтовариство до розвитку співробітництва 3 метою забезпечення безперешкодного інформаційного обміну, що призвело до створення сукупності міжнародних норм і принципів, які охоплюються міжнародно-правовим інститутом захисту приватності персоніфікованої інформації. 


\section{2. Свропейський досвід забезпечення права на приватність персоніфікованої інформації \\ та шляхи його впровадження для України}

Деякі провідні фахівці у галузі державного управління та захисту персональних даних (О. Волков ${ }^{16}$, Н. Докучаєва ${ }^{17}$, Д. Павленко ${ }^{18}$ та інші) розглядають принципи захисту персональних даних у зарубіжних країнах та міжнародні правові акти, що регламентують відносини у сфері захисту персональних даних. Однак у публікаціях не досить досліджено міжнародні та європейські стандарти щодо захисту персональних даних, вивчення особливостей національних регулятивних підходів окремих держав до захисту персональних даних; не акцентовано увагу на різниці в підходах національного законодавства та основні орієнтири в процесі державного (національного) регулювання захисту персональних даних.

Право щодо захисту прав людини, як правова категорія, вперше виникло в Сполучених Штатах Америки в 1928 р., коли суддя Верховного суду Л. Брандейс офіційно заявив про наявність у Конституції США «права бути залишеним у спокої». Надалі інститут недоторканості особистого життя людини почав розглядатися як обов'язковий фактор розбудови демократичного суспільства. Історія формування законодавчої бази захисту персональних даних бере свій початок з 1948 р., коли в Загальній декларації прав людини ${ }^{19}$ було проголошено, що ніхто не може піддаватися свавільному втручанню в особисте та сімейне життя, що кожна людина має право на захист від такого втручання. Європейська Конвенція про захист прав і основоположних свобод людини від 4 листопада 1950 p. ${ }^{20}$ конкретизувала це право, проголосивши, що кожна людина має право на свободу дотримуватися своєї думки, отримувати й поширювати інформацію та ідеї без втручання з боку державних органів і незалежно від державних кордонів. Міжнародним

16 Волков А. Защита персональных данных: пригодится ли нам британский опыт? URL: http://www.ispdn.ru/publications/7312.

17 Докучаева Н. Феномен украинской визитницы, или Защита персональных данных по-украински. URL: http://pravotoday.in.ua/ru/press-centre/publications/pub-190.

18 Павленко Д. Як захистити персональні дані. URL: http://www.epravda.com.ua/ columns/2011/09/30/300156.

19 Загальна декларація прав людини : Декларація від 10 груд. 1948 р. Генеральна Асамблея OOH. URL: http://zakon3.rada.gov.ua/laws/show/995_015.

20 Про захист прав людини і основоположних свобод : Конвенція від 4 листоп. 1950 р. URL: http://zakon.rada.gov.ua/cgi-bin/laws/main.cgi?nreg=995_00. 
пактом про громадянські та політичні права від 16 грудня 1966 p. $^{21}$ забороняється не лише свавільне, а й незаконне втручання в особисте та сімейне життя людини.

Отже, зазначені міжнародні документи узагальнюють основні принципи захисту приватного життя людини. Актуальність більш детального регулювання цього права зросла у зв'язку з інтенсивним розвитком комп'ютерних технологій та обробкою персональної інформації в автоматизованих інформаційних системах. У рамках діяльності міжнародних організацій було прийнято низку міжнародних документів, що регулюють право на захист персональної інформації, серед яких можна виділити такі.

Уперше на законодавчому рівні Європейське Економічне Співтовариство заговорило про захист персональних даних після доповіді 1973 року. Не менш інтенсивно ця проблематика порушувалась у Європейському Парламенті і в 1974 та 1975 роках. Це був перший офіційний крок до узгодження політики країн Європейських Співтовариств $з$ приводу захисту персональних даних, основні положення якої були зазначені у Резолюції, що була ухвалена Радою ЄС у липні 1974 року.

У червні 1979 року Парламент ухвалив Резолюцію «Про захист прав індивідів стосовно технічного розвитку і обробки даних» $»^{22}$, де акцентувалась увага на можливості створення спільного ринку обробки даних, адже національні положення в галузі захисту приватних прав здатні «змінити умови конкуренції».

Подальший розгляд цього питання підштовхує до створення нових документів, що можуть визначати умови захисту персональної інформації, адже проблема транскордонної передачі даних за межі континенту стає актуальнішою і водночас не визначеною юридично.

Основними нормативно-правовими актами Європейського Союзу, що регулюють суспільні відносини у сфері захисту персональних даних, є Директива ЄС «Про захист фізичних осіб при обробці персональних даних і про вільне переміщення таких даних» від 24 жовтня 1995 року ${ }^{23}$, Директива СС «Стосовно обробки персональних даних і захисту права

21 Міжнародний пакт про громадянські і політичні права : Міжнародний пакт від 16 груд. 1966 p. URL: http://zakon4.rada.gov.ua/laws/show/995_043.

22 Про захист прав індивідів стосовно технічного розвитку і обробки даних : Резолюція Ради CC. URL: http://www.europa.eu.

23 Про захист фізичних осіб при обробці персональних даних і про вільне переміщення таких даних : Директива ЄС від 24 жовтня 1995 року. URL: http://www.europa.eu. 
на невтручання в особисте життя у телекомунікаційному секторі» від 15 грудня 1997 року ${ }^{24}$, Директива ЄC «Про обробку персональних даних та захист сектору електронних комунікацій» (Директива про секретність та електронні комунікації) від 12 липня 2002 року², Регламент Європейського парламенту та Ради ЄС «Про захист фізичних осіб, що стосується обробки персональних даних установами i органами Європейського Співтовариства i щодо вільного переміщення таких даних» від 18 грудня 2001 року ${ }^{26}$, рішення та рекомендації створеної згідно зі ст. 29 Директиви 95/46/СС в 1996 році постійно діючої Робочої групи з метою гармонізації європейського права в сфері захисту персональних даних та консультацій, рішення та рекомендації наглядових органів країн - учасниць $\mathrm{EC}^{27}$ тощо ${ }^{28}$. Новітній розвиток інформаційно-комунікаційних технологій зумовлює загострення багатьох проблем: збільшення цифрового розриву між розвиненими країнами та країнами, що розвиваються; можлива організація та контроль основних глобальних процесів на користь еволюційного розвитку суспільства; забезпечення захисту інформації про особу та водночас світової безпеки.

Як правильно зауважує Ю. Максименко, «становлення інформаційного суспільства має як безсумнівні позитивні, так і певні негативні наслідки. 3 одного боку, пришвидшилася передача інформації значного обсягу, прискорилась її обробка та впровадження. 3 іншого - серйозне занепокоєння викликає поширення фактів протизаконного збору i використання інформації, несанкціонованого доступу до інформаційних ресурсів, незаконного копіювання інформації в електронних системах, викрадення інформації з бібліотек, архівів, банків та баз даних, порушення технологій обробки інформації, запуску програмвірусів, знищення та модифікація даних у інформаційних системах,

24 Стосовно обробки персональних даних і захисту права на невтручання в особисте життя в телекомунікаційному секторі : Директива ЄC від 15 грудня 1997 року. URL: http://www.europa.eu.

25 Про обробку персональних даних та захист сектору електронних комунікацій : Директива EC. URL: http://www.europa.eu.

26 Про захист фізичних осіб, що стосується обробки персональних даних установами і органами Європейського Співтовариства і щодо вільного переміщення таких даних : Регламент Європейського парламенту та Ради CC. URL: http://www.europa.eu.

27 Рекомендація № R (99) 5 Комітету міністрів державам-членам щодо захисту приватності в Інтернеті. URL: http://www.europa.eu.

28 Рекомендація № R (90) 19 Комітету міністрів державам-членам про захист персональних даних, застосовуваних для сплати та інших споріднених операцій. URL: http://www.europa.eu. 
перехоплення інформації в технічних каналах іiі витоку, маніпулювання суспільною та індивідуальною свідомістю тощо» ${ }^{29}$.

Захист персональних даних в СС здійснюється в контексті побудови інформаційного суспільства в СС. Так, відповідно до стратегії розвитку «Свропейського інформаційного суспільства», прийнятої наприкінці 1999 року, Європейський Союз робить енергійні зусилля для подолання відстані між США та СС в інформаційній сфері. Серед пріоритетних напрямів досліджень, що активно фінансуються Комісіями СС, важливе місце відводиться розвитку індустрії інформації, передусім електронних засобів їх передачі, нагромадження й обробки, а також програмного забезпечення. Надаючи пріоритетну роль розвитку інформаційної сфери у житті суспільства, стратегія Євросоюзу вирізняється своєю відвертістю щодо впровадження соціальних технологій. Як зауважено, «втрата над контролем передачі інформаційних даних може привести до посилення контролю над особистістю, маніпуляцією одержаними даними, розрив між різними прошарками суспільства». Аналізуючи діяльність Європейського Співтовариства, що відбивається у законодавчих документах, маємо справу із принаймні десятьма дилемами. При цьому варто наголосити на тому, що йдеться про необхідність вибору саме між дилемами. Тобто слід обирати альтернативний шлях, коли одна 3 двох альтернатив більше відповідає ситуації, аніж інша. Оскільки масове інформування здійснюється за принципом загального інформування, тобто не є вибірково цілеспрямованим, то інформація, що поширюється подібними каналами масових комунікацій, може потрапляти до надто різних людей, які, своєю чергою, можуть використовувати ії з різними, іноді злочинними, намірами. Зрештою, йдеться про проблему безпеки передачі персональних даних і діяльності засобів масових комунікацій ${ }^{30}$.

Отже, важко заперечувати ситуації, за умов яких уповноважені на те державні органи мають право призупиняти дію гарантованого чинним законодавством масового інформування та жорстко регламентувати таке інформування для безпеки суспільної й персональної. 3 точки зору загальноправової $\epsilon$ чітко визначені загальні положення,

29 Максименко Ю.С. Теоретико-правові засади інформаційної безпеки України : автореф. дис. на здобут. ступеня к. ю. наук : спец. 12.00.01 «Теорія та історія держави і права; історія політичних і правових учень». Київ, 2007. 23 с.

30 Саєнко М.I. Практичний досвід країн ЄС щодо захисту персональних даних. Development of modern technologies and scientific potential of the world : coll. of scientific papers " $\Lambda$ ОГО $\Sigma$ " with materials of the International scientific-practical conf., London, July 29, 2019. London: NGO "European Scientific Platform”, 2019. V. 2. Pp. 38-45. 
які мають обмежувати права громадян на збереження таємниці персональних даних.

Незважаючи на наявність відповідного нормативно-правового регулювання суспільних відносин у сфері захисту персональних даних, говорити про ефективну охорону приватного життя у європейських країнах неможливо. Так, відповідно до результатів дослідження, що було проведене експертами Ради Свропи, було неодноразово засвідчено численні втручання у приватне життя засобами масової інформації. Причиною такої ситуації є надзвичайна прибутковість публікацій, що пов'язана 3 приватною стороною життя відомих людей. 26 червня 1998 року в Резолюції Асамблеї Ради Європи № $1165^{31}$ проголошені керівні принципи щодо зміни законодавства у сфері захисту приватної інформації.

Досить логічно визначені основні пріоритети гарантів захисту особам, які зазнають втручання у їхне приватне життя. Вони мають право на захист у цивільному порядку, а саме на спрощений та прискорений розгляд справ; публічне спростування неправдивої інформації; компенсацію моральної шкоди; судові заборони на переслідування та домагання.

Не менш великого значення мають і превентивні заходи. Так, серед превентивних заходів, що застосовуються до засобів масової інформації, передбачаються такі як: наявність правової освіти у журналістів; застосування економічних санкцій до редакції засобів масової інформації, що систематично порушують права на приватність; постійні заохочення до саморегулювання засобів масової інформації та розроблення кодексу поведінки журналістів. Такий порядок міжнародного співробітництва з питань регулювання захисту приватної інформації в засобах масової інформації стикається з проблемою різних національних підходів і розбіжностями щодо проблеми узгодження права на приватність персоніфікованої інформації і свободи слова.

Тому національні правові системи деяких європейських країн обирають різні підходи для захисту персоніфікованої інформації. У Бельгії, Іспанії, Португалії і Швеції законодавство із захисту приватності однакове для всіх галузей застосування і не містить спеціальних винятків, навіть для будь-яких засобів масової інформації.

Систематизуючи нормативно-правові акти окремих європейських країн, що регулюють суспільні відносини в сфері захисту персональних

\footnotetext{
31 Резолюція Асамблеї Ради Європи № 1165 від 26 червня 1998 року. URL: http://www.evropa.eu.
} 
даних, можна дійти висновку, що більшість законодавчих актів у цій сфері мають однакову структуру, однакові завдання і мету, але відрізняються окремими деталями, що зумовлені національними правовими традиціями, а також особливостями правового регулювання персональної інформації в різних національних правових системах.

\section{ВИСНОВКИ}

Міжнародні стандарти захисту приватності персоніфікованої інформації містять відповідні норми й принципи, спрямовані на забезпечення безперешкодності передачі інформації через кордони. Однак ця мета нерозривно пов'язана із міжнародно-правовим захистом права людини на приватність персональної інформації, що становить головний елемент усього правового механізму регулювання транскордонної передачі персоніфікованої інформації. Невідповідність національних правових положень у галузі персональної інформації міжнародно-правовим стандартам загрожує застосуванням обмежень на передачу персональної інформації громадян інших країн до України, а це матиме негативні політичні й економічні наслідки для держави і вітчизняних суб'єктів господарювання, створюватиме перешкоди для міжнародного співробітництва в багатьох сферах.

Таким чином, вивчення Україною європейського досвіду щодо правових механізмів регулювання захисту персональних даних та врахування основних принципів організації заходів стосовно контролю за виконанням законодавства у цій галузі відкриває можливості привести у відповідність до стандартів СС вітчизняні закони та підзаконні акти з тим, щоб втілити їх у життя в інтересах українських громадян. У подальшому вбачається за доцільне дослідження впливу європейського досвіду щодо правових механізмів регулювання захисту персональних даних, правового регулювання обробки персоніфікованої інформації та вдосконалення організаційно-правового забезпечення захисту персональних даних України з метою забезпечення його ефективного захисту. Надзвичайно цікавим із наукової точки зору й практично корисними для нашої держави будуть дослідження правового регулювання захисту приватності персоніфікованої інформації в праві Свропейського Союзу та питання запровадження загальноєвропейських правових стандартів захисту приватності персоніфікованої інформації. 


\section{АНОТАЦІЯ}

У дослідженні аналізуються теоретико-правові засади регулювання персоніфікованої інформації в аспекті світових тенденцій розвитку інформаційних технологій. Розкрито базові поняття і принципи персоніфікованої інформації іï приватного характеру. Висвітлено наявність багатьох європейських та трансатлантичних інститутів і організацій, що беруть участь у забезпеченні безпеки збереження та передачі персоніфікованої інформації про особу, що свідчить про серйозність обговорюваної проблеми та необхідність створення нових стандартів, а також розподіл відповідальності та координацію їх діяльності.

Проблема захисту права на приватність персоніфікованої інформації має розв'язуватися з точки зору права власності конкретної людини на свої персональні дані. Має бути поєднання принципу недоторканності особи з принципом, який свідчить, що основою свободи $є$ власність і замах на неї рівнозначний обмеженню свободи. Інакше кажучи, особливої уваги потребує проблема врегулювання балансу інтересів сторін: особистості, суспільства і держави на основі механізму збалансованості інтересів. Аналіз національної нормативно-правової бази з питань захисту права на приватність персоніфікованої інформації свідчить, що натепер правове забезпечення суспільних відносин в Україні щодо персональних даних у частині ïх правового захисту є недостатнім; законодавству з питань захисту персональних даних України притаманна низка таких суттєвих недоліків, як: фрагментарність, неузгодженість законодавчих актів між собою, недостатня чіткість, конкретність та відповідність європейському законодавству тощо.

Вивчення європейського досвіду з правових механізмів регулювання захисту персоніфікованої інформації та врахування основних принципів щодо організації заходів із контролю за виконанням законодавства у цій галузі окреслює коло напрямів, які допоможуть привести у відповідність до стандартів ЄС національне законодавство та втілити його в приватних інтересах українських громадян.

Необхідно акцентувати, що конструктивним для адаптації у національному законодавстві $€$ можливість забезпечення механізмів, які дають змогу суб' єкту персоніфікованої інформації контролювати зміст i наявність його персональних даних, а також вимагати їх виправлення; обмеження обсягу і використання персоніфікованої інформації переліком цілей, для яких вона призначена, які не можуть бути змінені без згоди суб' єкта персоніфікованої інформації; посилений режим охо- 
рони особливих категорій персоніфікованої інформації (національна приналежність, погляди і переконання, здоров'я та інтимне життя).

У подальшому видається за доцільне дослідження впливу міжнародних стандартів та досягнень загальної теорії права у сфері захисту права на приватність персоніфікованої інформації для приведення у відповідність до міжнародних орієнтирів організаційно-правового забезпечення права на приватність персоніфікованої інформації в Україні.

\section{ЛІТЕРАТУРА}

1. Азаров Д.С. Кримінальна відповідальність за злочини у сфері комп'ютерної інформації : автореф. дис. на здобуття ступеня к. ю. наук : 12.00.08. Київ, 2003. 18 с.

2. Конституція України : Закон України станом на 20.02.2020 p. URL: http://zakon4.rada.gov.ua/laws/show/254к/96-вр/ (дата звернення: 20.02.2020).

3. Жуковська О. Право на свободу слова та інформації в українському законодавстві та судовій практиці (деякі аспекти проблеми). Свобода висловлювань і приватність. 2002. № 2. С. 4-12.

4. Захаров Є. Аналіз доступу до інформації про незаконні дії співробітників правоохоронних органів. Свобода висловлювань $і$ приватність. 2002. № 2. C. 12-16.

5. Іванов В.Ф. Інформаційне законодавство: український та зарубіжний досвід. Київ : Центр вільн. преси, 1999. 210 с.

6. Важорова М.А. История возникновения и становления института персональных данных. URL: http://www.moluch.ru/conf/law/archive/37/365.

7. Права человека и защита персональных данных / за ред. А.А. Баранова. Киев: Гос. комитет связи и информации Украины, 2000. $280 \mathrm{c}$.

8. Костецька Т.А. Право на інформацію в Україні. НАН України; Ін-т держави і права ім. В.М. Корецького. Київ : Вища шк. права. 1998, C. $5,25,28,31$.

9. Брижко В.М. Організаційно-правовий захист персональних даних. Бюлетень з обміну досвідом роботи. 2003. № 144. С. 27-33.

10. Павленко Д. Як захистити персональні дані. URL: http://www.epravda.com.ua/columns/2011/09/30/300156.

11. Джинчарадзе Н.Г. Інформаційна культура. Київ : Укр. пропілеї; $1999,148 \mathrm{c}$.

12. Стефанчук Р.О. До питання забезпечення цивільно-правової охорони приватного життя фізичної особи: досвід України та Німеччини. Університетські наукові записки. 2005. № 4 (16). С. 68-72. 
13. Обуховська T.I. Теоретичні засади регулювання інформації про особу в умовах розвитку інформаційних технологій. Вісник НАДУ. 2015. № 2. C. 120-125.

14. Prosser William L. Handbook of the Law of Torts. St. Paul : West Publication Corp., 1964. P. 810-81.

15. Stromholm S. La protection de la vie privee - essai demorphologie juridique compare. Copyright and jurisprudence. 1983. Р. 213-238.

16. Волков А. Защита персональных данных: пригодится ли нам британский опыт? URL: http://www.ispdn.ru/publications/7312.

17. Докучаева Н. Феномен украинской визитницы, или Защита персональных данных по-украински. URL: http://pravotoday.in.ua/ru/ press-centre/publications/pub-190.

18. Загальна декларація прав людини від 10 грудня 1948 р. Генеральна Асамблея OOH. URL: http://zakon3.rada.gov.ua.

19. Про захист прав людини і основоположних свобод : Конвенція від 4 листопада 1950 p. URL: http://zakon.rada.gov.ua.

20. Міжнародний пакт про громадянські i політичні права : Міжнародний пакт від 16 грудня 1966 p. URL: http://zakon4.rada.gov.ua.

21. Про захист прав індивідів стосовно технічного розвитку і обробки даних : Резолюція Ради CC. URL: http://www.europa.eu.

22. Про захист фізичних осіб при обробці персональних даних і про вільне переміщення таких даних : Директива ЄС від 24 жовтня 1995 року. URL: http://www.europa.eu.

23. Стосовно обробки персональних даних i захисту права на невтручання в особисте життя в телекомунікаційному секторі : Директива ЄС від 15 грудня 1997 року. URL: http://www.europa.eu.

24. Про обробку персональних даних та захист сектору електронних комунікацій : Директива EC. URL: http://www.europa.eu.

25. Про захист фізичних осіб, що стосується обробки персональних даних установами і органами Європейського Співтовариства і щодо вільного переміщення таких даних : Регламент Європейського парламенту та Ради CC. URL: http://www.europa.eu.

26. Рекомендація № R (99) 5 Комітету міністрів державам-членам щодо захисту приватності в Інтернеті. URL: http://www.europa.eu.

27. Рекомендація № R (90) 19 Комітету міністрів державам-членам про захист персональних даних, застосовуваних для сплати та інших споріднених операцій. URL: http://www.europa.eu.

28. Максименко Ю.С. Теоретико-правові засади інформаційної безпеки України : автореф. дис. на здоб. ступеня к. ю. наук : спец. 12.00.01 «Теорія та історія держави і права; історія політичних і правових учень». Київ, 2007. $23 \mathrm{c}$. 
29. Саєнко М.I. Практичний досвід країн $\mathrm{CC}$ щодо захисту персональних даних. Development of modern technologies and scientific potential of the world: coll. of scientific papers " $\Lambda$ 'ОГО $\Sigma$ " with materials of the International scientific-practical conf., London, July 29, 2019. London : NGO “European Scientific Platform”, 2019. V. 2. Pp. 38-45.

\section{Information about author:}

Saienko M. I.,

Ph.D., Associated Professor of the Theory and History of State and Law Department Dnipropetrovsk State University of Internal Affairs 26, Gagarina avenue, Dnipro, Ukraine DOI https://doi.org/10.30525/978-9934-588-43-3/2.17 